\title{
The use of green macroalgae (Ulva lactuca and Codium tomentosum) that have a high methane potential, as a source of biogas in Senegal
}

Halima MAIGUIZO-DIAGNE1,3, Ndeye Aida NDIAYE'1,2, Yacine NDOUR-BADIANE ${ }^{1,4}$, Dominique MASSE4, Michel TORRIJOS5, Philipp SOUSBIE5 ${ }^{5}$, Mohamed Lamine GAYE², Ibrahima NDOYE³, Jérôme HAMELIN5, Saliou FALL'1

1. ISRA / Laboratoire National de Recherches pour les Productions Végétales (LNRPV), Laboratoire Commun de Microbiologie (ISRA-IRD-UCAD), Laboratoire Mixte International LAPSE, BP: 3120, Route des hydrocarbures, Dakar, Sénégal.

2. Département de Chimie et Biochimie, Université Cheikh Anta Diop (UCAD), Av. Cheikh Anta DIOP, BP: 5005, FannDakar, Sénégal.

3. Département de Biologie Végétale, Université Cheikh Anta Diop (UCAD), LAPSE, Av. Cheikh Anta DIOP, BP: 5005, Fann-Dakar, Sénégal.

4. IRD, Laboratoire Mixte International IESOL, BP: 1381, Route des hydrocarbures, Dakar, Sénégal.

5. LBE, Univ Montpellier, INRA, Narbonne, France.

Corresponding author: Halima MAIGUIZO-DIAGNE /email: maiguizo@yahoo.com

Original submitted in on $16^{\text {th }}$ November 2018. Published online at www.m.elewa.org on $31^{\text {st }}$ December 2018 https://dx.doi.org/10.4314/jab.v132i1.2

\section{ABSTRACT}

Anaerobic digestion is a biochemical process that occurs naturally in the absence of oxygen. It is used commonly in developing countries to produce both energy and biofertilizers.

Objective: The purpose of this work was to study the anaerobic digestion of green macroalgae (Ulva lactuca and Codium tomentosum), which cause severe environmental problems in Dakar-Senegal, and elsewhere along Africa's Atlantic coast.

Methodology and Results: These green macroalgae were characterized in terms of physicochemical properties and biochemical methane potential (BMP). Their characteristics were compared to those of other locally available feedstock, such as cow manure and Jatropha curcas cake. The results showed that volatile solids of macroalgae were about $500 \mathrm{~g} \mathrm{VS} / \mathrm{kg}$ and twice that of cow manure. Furthermore, the methane potential of macroalgae was twice (216.4 L CH$/ \mathrm{kg} \mathrm{VS}$ ) that of cow manure (100.3 L CH$/ 4 \mathrm{~kg} \mathrm{VS).} \mathrm{The} \mathrm{green} \mathrm{macroalgae}$ achieved a heating value potential of $2151 \mathrm{kWh} / \mathrm{t} \mathrm{VS}$. The methane potential of Jatropha cake as a substrate for anaerobic digestion was intermediate (133.6 L CH$/ \mathrm{kg}$ VS) but contained a large quantity of lignin (34\%), a slowly biodegradable organic substance.

Conclusions and application of findings: This study results showed that green macroalgae could be used as a substrate for the production of renewable energy the biogas in Senegal.

Keywords: Biogas, renewable energy, biochemical methane potential, macroalgae, Jatropha curcas. 


\section{INTRODUCTION}

Like many coastal ecosystems around the world, the coasts of the Atlantic Ocean are cyclically invaded by macroalgae (Morand, P. and Merceron 2005), which are opportunist seaweeds from coastal eutrophic ecosystems. One of the causes of this phenomenon is the discharge of wastewater directly into the Atlantic Ocean, and, more specifically, Hann Bay, which is located off the village of Hann Bel-Air, in Senegal. Large amounts of salts in seawater can reduce pollution from wastewater, but the increase in organic nutrients promotes the proliferation of macroalgae during the cold season. The green marine macroalgae of Hann Bay are dominated by two mains species: Ulva lactuca and Codium tomentosum. Ulva lactuca is a thin, flattened thallus and Codium tomentosum is a green algae with thick, dark-green tubular strands arranged into branches. It has a sponge-like, somewhat velvety touch. Both species are very common around the world (Lohmann, M. 1995). Although they are considered edible (Chapman, V. J. and Chapman, D. J. 1980; Dacy-Vrillon, B. 1993), the fact that they grow in wastewater limits their use as a food source or in industrial applications. Macroalgae biomass often rots in Hann Bay or is collected and disposed of as trash in municipal landfills. Anaerobic biological treatment processes for the recycling of sewage, animal manure, agricultural residues, food waste and other types of waste is suitable for developing countries. It involves the degradation and stabilization of complexes of organic matter by a consortium of microorganisms into an energy-rich biogas that can be used as renewable energy instead of fossil fuels (Raposo et al., 2011). One cubic meter of biogas containing up to $60 \%$ methane has a calorific value of about $6 \mathrm{kWh}$ and is equivalent to 0.6 litres of fuel oil (Moletta 2011). Since biogas digester plants are relatively easy to build and biomass can be derived from various waste sources at low cost, the energy recovered from biogas is competitive. In Senegal and many other countries in Sub-Saharan Africa (SSA), manure from animals such as cows and horses are frequently used to produce biogas, whereas the need to replenish depleted soil is rising annually. Furthermore, anaerobic digestion is of much greater interest for the reduction of toxic compounds and pathogenic organisms in wastes (Ruíz, C. et al., 2002, Mao et al., 2015). Consequently, the fraction remaining after anaerobic digestion, called digestate, can be used as a safer fertilizer for depleted soil. The cultivation of Jatropha curcas has been proposed in SSA as a green alternative to fossil fuels. However, Jatropha curcas cake, which is the solid remaining after extraction of the non-edible oil from Jatropha seeds, contains toxic substances (Nafisa, A. et al., 2010), making it unsuitable for use as a source of animal fodder or for other purposes. As a result, Jatropha curcas cake was proposed as an alternative feedstock for biogas plants (Nafisa, A. et al., 2010). The anaerobic biodegradability of virtually any organic substrate can be determined using a series of tests, such as the biochemical methane potential test (BMP), which gives the maximal expected production of biogas from a substrate in the presence of active microbial communities. Additionally, the physicochemical composition of organic matter can be evaluated using Van Soest fractionation to quantify concentrations of hemicelluloses, cellulose and lignin, the total organic matter content, and the carbon/nitrogen ratio. These analyses are commonly used to predict the behaviour of anaerobic digestion substrates (Torrijos 2008; Vanegas and Bartlett 2013). Many studies have been conducted to estimate the real feasibility and sustainability of the utilization algal biomass (Morand and Merceron 2005), including marine species such as Saccorhiza polyschides, Ulva sp. Laminaria digitata, Fucus serratus, and Saccharina latissimi (Singh, A.et al. 2011; Bastianoni, S. et al. 2008; Jard et al. 2012; Vanegas and Barlett 2013). The purpose of the present investigation was to study the biogas potential of two green macroalgae (Ulva lactuca and Codium tomentosum) from Hann Bay, Dakar, Senegal. These macroalgae harvested in Senegal have never been studied as a substrate for anaerobic digestion. The biogas potential of the two macroalgae was compared to the well-studied cow manure and Jatropha curcas cake, which is a by-product of the petroleum industry and could be produced in large quantities in Senegal. 


\section{MATERIALS AND METHODS}

Feedstock sample collection: Samples were collected in the Senegalese towns of Dakar and Nioro. Cow manure and macroalgae manure were sampled around
Dakar's Hann Bay and Sangalkam, a town around $18 \mathrm{~km}$ from Dakar. In Nioro, Jatropha curcas cakes were sampled from an artisanal processing unit.

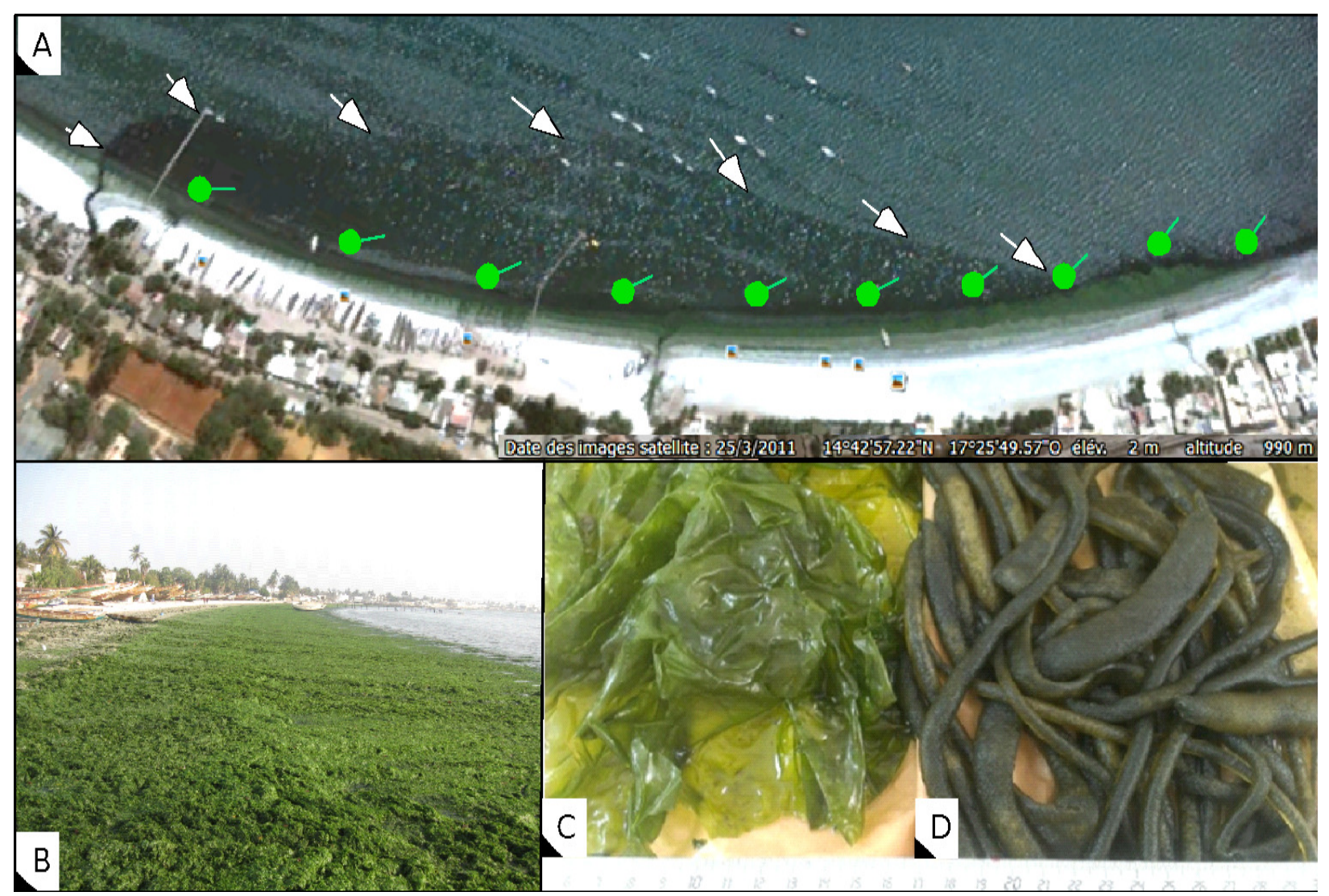

Figure 1: Origin and extent of the main macroalgae recovered from Hann Bay. Aerial view of the wastewater pollution (white arrows) resulting in the macroalgae proliferation (green circles with lines) in Hann Bay investigated in this study (A); Extent of the macroalgae (B); The two main species, Ulva lactuca $(\mathrm{C})$ and Codium tomentosum (D), recovered.

The dominant algal species (MAlg): Macroalgae are produced in huge quantities from prolific growth in eutrophic environmental conditions (Figure 1, A). Beached seaweed can measure around $50 \mathrm{~cm}$ deep in January (Figure 1, B). Samples were collected at four sites located about $200 \mathrm{~m}$ apart. The biomass on a surface $50 \times 50 \mathrm{~cm}$ and at ground level was collected and placed in separate plastic bags. The dry weight was determined on fresh organic matter. The rest of the feedstock collected was dried in an oven at $35^{\circ} \mathrm{C}$ for one week. The identification of Ulva lactuca and Codium tomentosum as the dominated species was confirmed by observations, with $76.5 \%$ and $17.9 \%$ respectively (Figure $1, C$ and $D)$.

Cow manure (Cwm): Manure is the excrement of ruminant mammals such as cattle and buffalo. The samples for this study were collected at a ranch in Sangalkam. They were taken from a mound prepared by the owners and generally consisting of a mixture of several crops over a long period (1 to 2 months). This type of manure is typically used as a soil amendment.

Jatropha curcas cake (Jcc): Consists of the by-products of the pressing of Jatropha curcas $L$. seeds. The samples were collected from three artisanal processing units using the same process to extract Jatropha curcas seed oil. For each sampling, about $1 \mathrm{~kg}$ of cake was collected from cake dried at room temperature.

Analytical methods: Total solids (TS) and volatile solids (VS) were determined on dry substrates according to APHA standard methods (APHA, 1992) by drying the biomass at $105^{\circ} \mathrm{C}$ for $24 \mathrm{~h}$ followed by incineration at $550^{\circ} \mathrm{C}$ for $2 \mathrm{~h}$. Fractionation of organic matter was 

tomentosum) that have a high methane potential, as a source of biogas in Senegal

performed using the Van Soest method (Soest VP, 1991). Total Kjeldahl Nitrogen (TKN) was measured using the normalized method (Dunod, 1975). Total organic carbon was measured by catalytic combustion using a TOC-V series analyzer (Shimadzu Corporation, 2004). Total phosphorus was measured using the AFNOR method (AFNOR Paris, 2010). Cation ( $\mathrm{Na}^{+} ; \mathrm{K}^{+}$) concentrations were determined by ion exchange chromatography using the Chromeleon software. Lipids were measured using standard methods (APHA, 1992),

Biochemical methane potential (BMP): BMP was determined using an inoculum taken from the outlet of an upflow anaerobic sludge blanket (UASB) reactor used to treat wastewater from a sugar mill (Jard G. et al., 2012). The initial VS concentration of the sludge was around $110 \mathrm{~g} \mathrm{VS} / \mathrm{kg}$ VSS. The BMP tests were prepared in duplicate in $500 \mathrm{~mL}$ serum bottles with a $400 \mathrm{~mL}$ working volume according to the protocol described by Angelidaki et al., (Angelidaki et al., 2009). The SO/XO ratio used was 0.5 and each bottle contained $2 \mathrm{~g}$ VSS of inoculum and $1 \mathrm{~g} \mathrm{VS}$ of substrate. The bottles were filled to $400 \mathrm{~mL}$ with a bicarbonate buffer supplemented with nutrients. Positive and negative controls containing either a fully biodegradable compound (ethanol) or no substrate were prepared. The bottles were rapidly sealed using butylrubber stoppers held with clamped aluminium collars. Nitrogen gas was flushed into the airspace in order to remove traces of oxygen and maintain anaerobic

\section{RESULTS AND DISCUSSION}

Biochemical composition, total solids (TS) and volatile solids (VS): The total solids (Table 1) in the macroalgae $(851.4 \mathrm{~g} \mathrm{TS} / \mathrm{kg})$ were significantly higher $(p<0.0001)$ compared to cow manure and Jatropha curcas cake (742.4 and $797.4 \mathrm{~g} \mathrm{TS} / \mathrm{kg}$, respectively). More interesting, the volatile solids of the macroalgae were $499.8 \mathrm{~g} \mathrm{VS} / \mathrm{kg}$ and about twice that of cow manure $(251.3 \mathrm{~g} \mathrm{VS} / \mathrm{kg}$ ), which is a substrate usually used for anaerobic digestion. However, the volatile solids and the VS/TS ratio (Table 1) were higher with Jatropha curcas cake $(699.9 \mathrm{~g} \mathrm{VS} / \mathrm{kg}$ and $87.7 \%)$. The mineral composition (Table 1) was significantly higher ( $p<$ 0.0001 ) for the cow manure ( $357.5 \mathrm{~g} / \mathrm{kg}$ TS) compared to the macroalgae (109.6 $\mathrm{g} / \mathrm{kg}$ TS) and the Jatropha curcas cake $(24.8 \mathrm{~g} / \mathrm{kg}$ TS). Total solids measurements show that all the substrates studied in this work were quite dry. Indeed, all TS contents were above $740 \mathrm{~g} \mathrm{TS} / \mathrm{kg}$. In particular, the total solids contents of the macroalgae were consistent with other published data (Ward et al. 2014). Cow manure and most other types of animal conditions. Once prepared, the bottles were shaken thoroughly and incubated at $35^{\circ} \mathrm{C}$ under gentle shaking for 60 days. The biogas volume and composition were measured at frequent intervals during the incubation period.

Inoculum: The bottles were seeded with anaerobic sludge taken from the outlet of an anaerobic reactor treating distillery vinasse at a suspended solid concentration (VSS) around $12 \mathrm{~g} \mathrm{VSS/l}$ (Torrijos, 2008).

Sampling and analysis: The biogas composition was determined using a gas chromatograph (Shimadzu, 2004) connected to a C-R8A integrator and equipped with a CTRI Altech column. The following gases were measured: $\mathrm{CO}_{2}, \mathrm{H}_{2}, \mathrm{O}_{2}, \mathrm{~N}_{2}$ and $\mathrm{CH}_{4}$. The margin for error of this measurement was $5 \%$. The endogenous biogas production obtained from the negative control was subtracted from the biogas obtained with the samples over the incubation period. Methane yields were calculated by dividing the corrected methane volume (standard pressure and temperature) by the weight of sample VS added.

Statistical analyses: Except for the physicochemical analysis, the analyses were run in three replicates and results are presented as the average \pm standard deviation. The averages were compared two by two using the Student's t-test implemented in the XLSTAT software (2007) at a significance level of $5 \%$.

manure are rich in organic matter and often contain the microorganisms involved in the aerobic and anaerobic processes necessary for biogas production (Moletta René 2011). This explains why it has always been preferred for biogas production, especially in rural areas of West Africa. Cow manure had a very high TS content indicating that it was very dry compared to cow manure analysed in other parts of the world. However, its VS content was low compared to the TS content and the organic fraction represented only $34 \%$ of the TS. This study results showed that volatile solids of macroalgae were about $500 \mathrm{~g} \mathrm{VS} / \mathrm{kg}$ and twice as high as those of cow manure, suggesting that macroalgae will be worthwhile for anaerobic digestion. The volatile solids are primarily composed of fatty acids, proteins and hydrocarbons, which are more biodegradable than some hydrocarbons (Godbout, 2010). Moreover, Habig and Ryther (Habig and Ryther, 1984), found a significant correlation between the methane yields and acid-soluble carbohydrate content of some macroalgae, including Ulva sp. 
Table 1: Solid composition, lipid content and Van Soest fractionation for the three organic substrates used in this study

\begin{tabular}{|c|c|c|c|c|c|c|c|}
\hline & \multicolumn{4}{|c|}{ Solid composition } & \multicolumn{2}{|c|}{ Van Soest fractionation } & Lipids \\
\hline & $\begin{array}{c}\text { Total solids } \\
\text { g TS/kg }\end{array}$ & $\begin{array}{c}\text { Volatile } \\
\text { solids } \\
\text { g VS } / \mathrm{kg}\end{array}$ & $\begin{array}{l}\text { Mineral } \\
\mathrm{g} / \mathrm{kg} \text { TS }\end{array}$ & $\begin{array}{c}\text { VS/TS } \\
\text { (\%) }\end{array}$ & $\begin{array}{c}\text { Cellulose } \\
\text { fraction } \\
\text { (Cellulose + } \\
\text { Hemicellulose) } \\
\text { g/kg TS }\end{array}$ & $\begin{array}{l}\text { Lignin } \\
\text { g/kg TS }\end{array}$ & $\mathrm{g} / \mathrm{kg} T S$ \\
\hline MAlg & $851.4 \pm 6.4$ & $499.8 \pm 4.4$ & $\begin{array}{c}109.6 \pm \\
1.0\end{array}$ & 58.70 & $428.3 \pm 8.7$ & $206.5 \pm 1.5$ & $25.1 \pm 0.8$ \\
\hline Cwm & $742.4 \pm 2.2$ & $251.3 \pm 7.9$ & $\begin{array}{c}357.5 \pm \\
6.3\end{array}$ & 33.85 & $254.2 \pm 6.3$ & $243.5 \pm 3.9$ & $2.3 \pm 1.5$ \\
\hline$J c c$ & $797.5 \pm 5.8$ & $699.9 \pm 8.8$ & $24.8 \pm 4.8$ & 87.78 & $113.5 \pm 6.1$ & $339.2 \pm 2.5$ & $8.21 \pm 1.7$ \\
\hline
\end{tabular}

On the other hand, the lipids content of the macroalgae $(25.1 \mathrm{~g} / \mathrm{kg}$ TS) was ten times higher in the macroalgae than in the cow manure $(2.3 \mathrm{~g} / \mathrm{kg} \mathrm{TS})$ and about three times higher $(8.2 \mathrm{~g} / \mathrm{kg}$ TS) in the Jatropha curcas cake. The differences in lipids were less but remained significant $(p<0.0106)$. The high lipids values $(25.8 \mathrm{~g} / \mathrm{kg}$ TS) and the high proportion of cellulose fractions (cellulose and hemicelluloses) in the macroalgae are also a worthwhile source of energy for biogas production. The cellulose fraction concentration determined by Van Soest fractionation (Table 1) show values significantly higher $(p<0.0001)$ in the macroalgae $(428.3 \mathrm{~g} / \mathrm{kg}$ TS) than in the Jatropha curcas cake (254.2 g/kg TS) or the cow manure $(113.5 \mathrm{~g} / \mathrm{kg}$ TS). The cellulose fraction in the macroalgae was four times higher than in the cake. All substrates had quite a high content in lignin a very slowly or no degradable substrate by anaerobic digestion. The lignin concentration $(206.5 \mathrm{~g} / \mathrm{kg} \mathrm{TS})$ in the macroalgae was significantly lower $(p<0.0001)$ than in the other substrates. Furthermore, an analysis of macroalgae for food and pharmaceutical uses revealed the presence of large quantities of a source of polysaccharides (Mabeau, S. and Fleurence 1993). Their biochemical properties mean that algae are digested very quickly, which is not conducive to sustainable biogas production. To overcome this rapid degradability of algae, Yen and Brune (Yen and Brune, 2007) balanced this low carbon content by means of co-digestion of waste paper with microalgae. In doing so, they increased the biogas production by more than half that without co-digestion. For future applications, biogas production from algae can be improved over time by co-digestion with other substrates. In contrast to the macroalgae, the Jatropha curcas cake had a high lignin content $(339.2 \mathrm{~g}$ lignin $/ \mathrm{kg}$ TS $>113.5 \mathrm{~g}$ cellulose fraction $/ \mathrm{kg} \mathrm{TS}$ ), which may inhibit methanogenic microorganisms (Moletta René, 2011), and can subsequently reduce methane production.

Physicochemical characterization: The carbon, nitrogen and total phosphorous contents of the macroalgae were $115.1 \mathrm{~g} \mathrm{C} / \mathrm{kg} \mathrm{TS}, 13.3 \mathrm{~g} \mathrm{~N} / \mathrm{kg}$ TS and $48.1 \mathrm{~g} \mathrm{P} / \mathrm{kg}$ TS, respectively (Table 2). The Jatropha curcas cake had much higher carbon and phosphorus contents $(401.6 \mathrm{~g} \mathrm{C} / \mathrm{kg}$ TS and $15.70 \mathrm{~g} \mathrm{P} / \mathrm{kg}$ TS) but a relatively lower nitrogen content (12.9 g N/kg TS). The carbon and nitrogen contents in the cow manure were intermediate $(253.7 \mathrm{~g} \mathrm{C} / \mathrm{kg}$ TS and $12.9 \mathrm{~g} \mathrm{~N} / \mathrm{kg} \mathrm{TS}$, respectively). The microalgae displayed the lowest $\mathrm{C} / \mathrm{N}$ ratio, of about 8.7, as compared to 19.7 and 32.4 for the cow manure and the Jatropha curcas cake, respectively. Anaerobic digestion is sensitive to the $\mathrm{C} / \mathrm{N}$ ratio. $\mathrm{A}$ high $\mathrm{C} / \mathrm{N}$ ratio provides insufficient nitrogen whereas a low ratio reflects a high nitrogen content in substrates, which can lead to inhibition of the anaerobic process (Fricke K. et al., 2007). A C/N ratio of 8.7 was found for macroalgae, which was in agreement with previous results obtained in multiple macroalgae species (Ward et al., 2014). The C/N ratio values of cow manure and Jatropha curcas cake (20 and 36 , respectively) were closer to a ratio of 25 , which is the most commonly recommended ratio (Mao C., 2015). 
Table 2: Basic composition of the three organic substrates used in this study (in $\mathrm{g} / \mathrm{kgTS}$ ).

\begin{tabular}{|c|c|c|c|c|c|c|c|c|}
\hline & C & $\mathrm{N}$ & $\mathrm{C} / \mathrm{N}$ & $P$ total & $\mathrm{Ca}$ & $\mathbf{M g}$ & K & $\mathrm{Na}$ \\
\hline MAlg & 115.1 & 13.3 & 8.7 & 4.8 & 17.5 & 15.0 & 12.3 & 35.3 \\
\hline Cwm & 253.7 & 12.9 & 19.7 & 6.4 & 18.7 & 3.9 & 2.2 & 1.6 \\
\hline Jcc & 401.6 & 12.4 & 32.4 & 15.7 & ND & ND & 3.8 & 2.1 \\
\hline
\end{tabular}

C, Carbon; N, Nitrogen; P, Total Phosphorus; Ca, Calcium; Mg, magnesium; K, Potassium; Na, Sodium

The salt content $\left(\mathrm{Mg}^{+}, \mathrm{K}^{+}\right.$and $\left.\mathrm{Na}^{+}\right)$was at least three times greater in the macroalgae than in the other substrates tested. Because of their marine origin, the macroalgae contained a higher $\mathrm{Na}^{+}$content than the terrestrial substrate studied (cow manure and Jatropha curcas cake). The high salt concentration of macroalgae has to be taken into account for the operation of a digester as these ions might inhibit anaerobic digestion at high concentrations. Dilution of the macroalgae in the feed with other substrates (co-digestion) will be proposed. Methane production and biogas composition: The BMP measurement of the three substrates lasted for more than two months (Figure 2). The net cumulative production of $\mathrm{CH}_{4}$ was reported over time and was higher for macroalgae than for cow manure and Jatropha curcas cake. Indeed, the cumulative methane volume reached about $216.4 \mathrm{~L} \mathrm{CH}_{4} / \mathrm{kg}$ VS for the macroalgae whereas it was less than $135 \mathrm{~L} \mathrm{CH}_{4} / \mathrm{kg}$ VS for the other substrates. The biogas composition was quite close for the three substrates tested and contained more than $55 \%$ of methane and less than $42 \%$ of carbon dioxide. In particular, the biogas composition of macroalgae contained at least $62 \%$ methane.

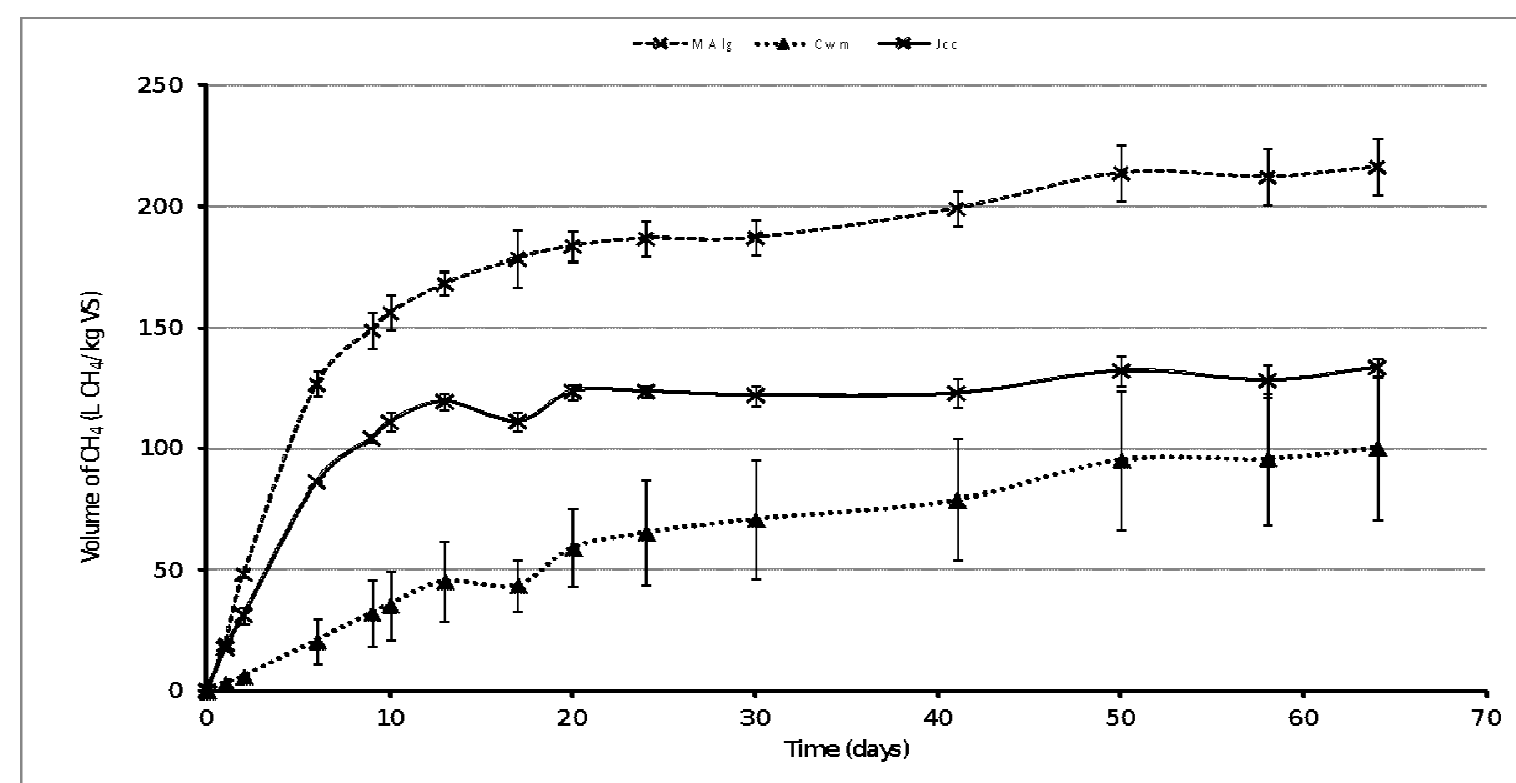

Figure 2: Cumulative production of methane $\left(\mathrm{CH}_{4}\right)$ measured from the three substrates investigated: Macroalgae (MAlg); Jatropha curcas cake (Jcc); Cow manure (Cwm). 


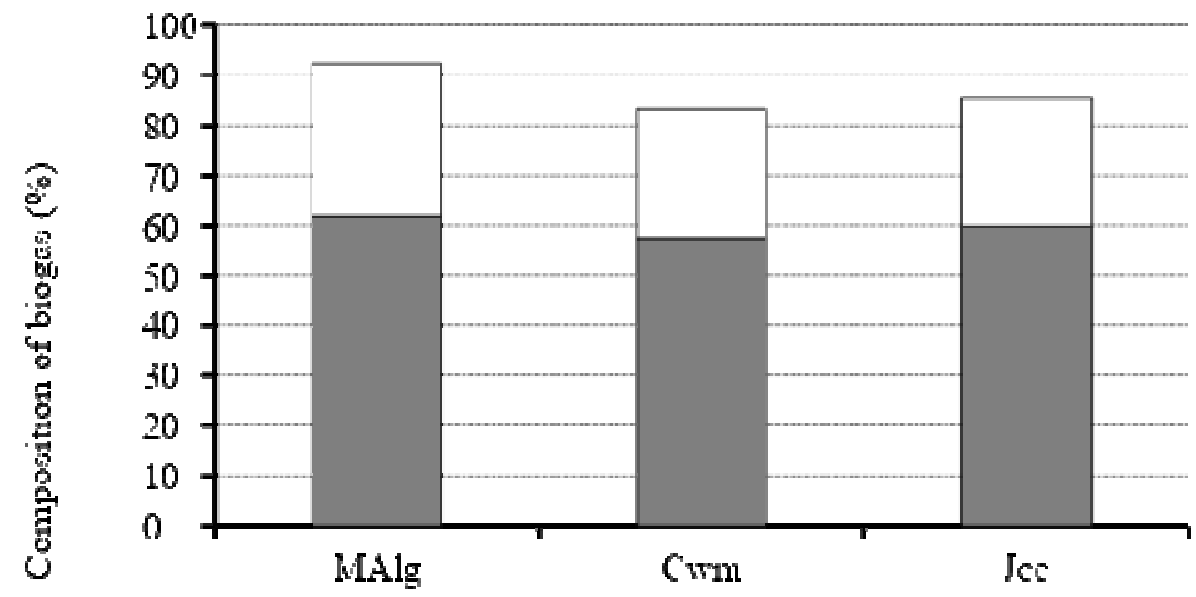

Figure 3: Composition of biogas (\%) from the three substrates. Methane ( $\mathrm{CH}_{4}: \mathrm{MAlg} 62 \%, \mathrm{Cwm} 58 \%$, Jcc $60 \%$ ): shaded part: Carbon dioxide $\left(\mathrm{CO}_{2}\right.$ : MAlg $38 \%$, Cwm $42 \%$, Jcc $\left.40 \%\right)$ : white part. The other gases $\left(\mathrm{O}_{2}\right.$ and $\left.\mathrm{H}_{2} \mathrm{~S}\right)$ are almost zero in the collected biogas. Nitrogen was not taken into account as was used as the carrier gas to expel the air in the BMP devices.

Table 3: Energy value of the three organic substrates based on BMP

\begin{tabular}{l|}
\hline Methane potential \\
( $\mathrm{L} \mathrm{CH}_{4} / \mathrm{kg} \mathrm{VS}$ )
\end{tabular}

\begin{tabular}{|l|}
\hline MAlg \\
\hline Cwm \\
\hline Jcc \\
\hline
\end{tabular}

\begin{tabular}{|l|}
\hline $216 \pm 12.0$ \\
\hline $100 \pm 29.5$ \\
\hline $134 \pm 04.1$ \\
\hline
\end{tabular}

\begin{tabular}{l|}
\hline $\begin{array}{l}\text { Heating value } \\
\text { (kWh/t) }\end{array}$ \\
\hline
\end{tabular}

\begin{tabular}{|c|}
\hline 2151 \\
\hline 997 \\
\hline 1328 \\
\hline
\end{tabular}

To investigate the maximum methane production capacity of the substrates studied, the biochemical methane potentials were calculated from the BMP tests performed (Table 3). The methane potential obtained for macroalgae (216.4 $\pm 12 \mathrm{~L} \mathrm{CH}_{4} / \mathrm{kg} \mathrm{VS}$ ) was higher than for Jatropha curcas cake (133.6 $\pm 0.4 \mathrm{~L} \mathrm{CH}_{4} / \mathrm{kg} \mathrm{VS}$ ) and cow manure $\left(100.3 \pm 29.5 \mathrm{~L} \mathrm{CH}_{4} / \mathrm{kg} \mathrm{VS}\right)$. The methane potential values with macroalgae were similar to those obtained by several authors with different species of algae (Costa et al., 2012, Vanegas and Bartlett 2013); including Saccharina latissima in batch reactor (Jard et al., 2012). For Jatropha curcas, the BMP values obtained by Gunaseelan (Gunaseelan, 2009) were $~ 230 \mathrm{LCH}_{4} / \mathrm{kg} \mathrm{VS}$ and about folds higher than the values obtained in this work. The same author showed also large variation of BMP tests according to the comportments of Jatropha (between 80 and $960 \mathrm{~L} \mathrm{CH}_{4} / \mathrm{kg} \mathrm{VS)}$. Therefore, these differences of BMP test for the Jatropha curcas cake are likely due to the source of seeds and process to obtain cakes. The methane potential of cow manure about $100 \mathrm{~L}$ $\mathrm{CH}_{4} / \mathrm{kg}$ VS, while the solid total solid was about $742.4 \mathrm{~g}$ $\mathrm{TS} / \mathrm{kg}$, this result apparently contradictory can be explained by the type of dung collected into sub-Sahara area, which are most of the time altered by the physical and chemical conditions they encounter after their expulsion by the animals. Moreover, the feeding of animals in semi-arid area provides little grass or hay and more dead leaf (Guwy A. J. et al., 2009). In sum, the samples analyzed showed a low bio-degradability of cow manure and Jatropha curcas cake compared to macroalgae. Sub-Sahara countries are, among other things, characterized by low crop production while the population energy requirements increase even of that, the need for organic matter to fertilize degraded soils. It is quite justified to invest in finding substrates with high methane potential to produce energy on both small (home) and large scale (semi-industry). Our results showed that methane potential of macroalgea was $108 \mathrm{~L}$ $\mathrm{CH}_{4} / \mathrm{g}$ raw mass, in opposition to only $25 \mathrm{~L} \mathrm{CH}_{4} / \mathrm{g}$ raw mass for cow manure. As illustrate in Figure 1, biomass of microalgae into the bay of Hann was available during the cold season (November to April) and of the order of several hundred tons in term of fresh matter, demonstrating that valorization of biomass of algae was 
more interesting. Furthermore, and in terms of heating value, the potential achieved by the green macroalgae was $2151 \mathrm{kWh} / \mathrm{t} \mathrm{VS}$ and about seven times higher that of the cow manure. This difference will be significant in developing countries, where traditional sources of energy are used to cook food. Biogas production in coastal areas can provide an alternative fuel source for cooking, electricity generation and the development of usual livelihoods. Jatropha curcas cake also owned a methane potential $(93.5 \mathrm{~L} \mathrm{CH} / \mathrm{g}$ raw mass) higher than the cow manure potential but has showed upper, lignin fraction

\section{CONCLUSION}

The enormous amount of non-recycled organic waste produced in Senegal requires efficient, economic and ecological solutions tailored to each type of waste. In this context, biogas production represents a core technology that can make use of the invasive macroalgae in Dakar's

\section{ACKNOWLEDGMENTS}

The authors gratefully acknowledge the French Embassy in Senegal for providing financial support as part of the U3E-2012 project; INRA (Laboratoire de Biotechnologie de l'Environnement) for their welcome and supply of the equipment needed for our study; and all the staff at

\section{REFERENCES}

A.F.N.O.R., 2010. Norme U, 42-246, Tour Europe, Paris.

Angelidaki I. Alves M., Bolzonella D., Borzacconi L., Campos J. L., 2009. Defining the biomethane potential (BMP) of solid organic wastes and energy crops: a proposed protocol for batch assays. Water Sci Technol. ; 59(5): 927-34. Doi: 10.2166/ wst.2009. 040

APHA (American Public Health Association) 1992.

Standard Methods for the Examination of Water and Wastewater (L. S. Clesceri, A. E. Greenberg \& R. R. Trussell, eds), 18th edition. American Public Health Association, Washington.

Bastianoni S., Coppola F., Tiezzi E., Colacevich A., Borghin F., Focardi S., 2008. Biofuel potential production from the Orbetello lagoon macroalgae: A comparison with sunflower feedstock. Biomass and Bioenergy 32 (7), 619628.

Chapman V. J. and Chapman D. J., 1980. Sea vegetables (algae as food for man). In: Seaweeds and their uses. Chapman \& Hall (ed.), London, pp. 62-97. was important in cake. Co-digestion of these two substrates (macroalgae and Jatropha curcas cake) will be the next steps to be tested in pilot tests in the laboratory. In fact, co-digestion of substrates will provide additional benefice including salt dilution and increasing of carbon content for macroalgae and lignin dilution for Jatropha curcas cake. In addition, the digestate generated as a byproduct of anaerobic co-digestion could be used as a nitrogen-rich fertilizer and replace the traditional use of cow manure.

Hann Bay as well as many other parts of Africa's Atlantic coast. Anaerobic digestion can turn a true environmental problem into a source of renewable energy and fertilizer in suburban and rural areas.

LRNPV-ISRA (Laboratoire National de Recherches sur les Produits Végétales), LCM-IRD (Laboratoire Commun de Microbiologie) and LBE-INRA, for their contribution and support.

Costa J., Gonçalves P., Nobre A., Alves M., 2012. Biomethanation potential of macroalgae Ulva spp. and Gracilaria spp. and in co-digestion with waste activated sludge. Bioresource Technology, 114, 320326.

Dacy-Vrillon B. 1993. Nutritional aspects of the developing use of marine macroalgae for the human food industry. International journal of Food Science and Nutrition 44, 23-35.

Dunod R., 1975. L'analyse de l'eau, vol. 1, p: 123-126.

Fricke K., Santen H., Wallmann R., Hüttner A., Dichtl N. 2007. Operating problems in anaerobic digestion plants resulting from nitrogen in MSW. Waste Management.

Godbout S., Verma M., Larouche J., Potvin L., Chapman A., Lemay, S., 2010. Methane production potential (B0) of swine and cattle manures--a Canadian perspective. Environmental technology, 31, 1371- 1379.

Gunaseelan, VN (2009) Predicting ultimate methane yields of Jatropha curcus and Morus indica from their chemical composition, Bioresource technology, [online] Available from: 
http://www.sciencedirect.com/science/article/pi i/S0960852409001175.

Guwy AJ, Kalyuzhnyi S., Jenicek P., Van Lier JB, 2009. Defining the biomethane potential (BMP) of solid organic wastes and energy crops: a proposed protocol for batch assays. Water Science \& Technology, 59.5, pp. 927 - 934.

Habig C., and Ryther JH, 1984. Some correlations between substrate compositions and biogas yields. Symposium Papers, Energy from Biomass and Waste, Institute of Gas Technology, Chicago 8, 817-832.

Jard G., Jackowiak D., Carrère H., Delgenes J., Torrijos M., Steyer J., Dumas C., 2012. Batch and semicontinuous anaerobic digestion of Palmariapalmata: Comparison with Saccharinalatissima and inhibition studies. Chemical Engineering Journal 209: 513519.

Lohmann M. 1995. Flore et faune du littoral p 34, Chantecler, ISBN 2-8034-2778-8.

Mabeau S. and Fleurence J., 1993. Seaweed in food products: biochemical and nutritional aspects. Trends in Food Science \& Technology.

Mao C., Feng Y., Wang X., Ren G., 2015. Review on research achievements of biogas from anaerobic digestion. Renewable and Sustainable Energy Reviews 45, 540555.

Moletta René, 2011. Méthanisation, $2^{\mathrm{e}}$ édition, Tec et Doc (ed.), Publication Lavoisier.

Morand, P. and Merceron, M. 2005. Macroalgal population and sustainability. Journal of Coastal Research, 21 (5), 1009-1020

Nafisa A, Kurchania AK, Swati B, 2010. Biomethanisation of Jatropha curcas defatted waste, Journal of Engineering and Technology Research, 2(3), 038-043,

Raposo F., Rubia M., Fernández-Cegrí V., Borja R. 2012. Anaerobic digestion of solid organic substrates in batch mode: An overview relating to methane yields and experimental procedures. Renewable and Sustainable Energy Reviews 16: 861877.

Ruíz C., Torrijos M., Sousbie P., LebratoMartínez J., Moletta R., Delgenès, J.P., 2002. Treatment of winery wastewater by an anaerobic sequencing batch reactor. Water science and technology. 45 (10) 219-24.

Shimadzu Corporation, 2004. User Manuel SSM-5000A for TOC-V series.

Singh A, Nigam PS, and Murphy JD, 2011. Renewable fuels from algae: an answer to debatable land- based fuel. Bioresource Technology, 102(1), 1016.

Soest VP, Robertson JB, Lewis BA, 1991. Methods for dietary fiber, neutral detergent fiber and nonstarch polysaccharides in relation to animal nutrition. Journal of dairy science.

Standard Methods 18th edition (1992), Oil and Grease: Introduction APHA 5520 A; Soxhlet.

Torrijos M, Thalla A, Sousbie P, Bosque F, Delgenes J, 2008. Anaerobic digestion of residues from production and refining of vegetable oils as an alternative to conventional solutions. Water Science \& Technology, 58 (9)) 1871-1878

Vanegas C. and Bartlett J. 2013. Green energy from marine algae: biogas production and composition from the anaerobic digestion of Irish seaweed species. Environmental Technology, 34(15), 2277-2283

Ward AJ, Lewis DM, and Green FB. 2014. Anaerobic digestion of algae biomass: a review. Algal Research, 5; 204-214.

Yen H.W. and Brune D. 2006. Anaerobic co-digestion of algal sludge and waste paper to produce methane. Bioresource Technology 98; 130-4. 